NASA/TM-2002-211363

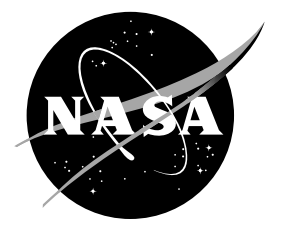

\title{
Exposure of Polymer Film Thermal Control Materials on the Materials International Space Station Experiment (MISSE)
}

Joyce Dever and Sharon Miller

Glenn Research Center, Cleveland, Ohio

Russell Messer and Edward Sechkar

QSS Group, Inc., Cleveland, Ohio

Greg Tollis

Cleveland State University, Cleveland, Ohio 
Since its founding, NASA has been dedicated to the advancement of aeronautics and space science. The NASA Scientific and Technical Information (STI) Program Office plays a key part in helping NASA maintain this important role.

The NASA STI Program Office is operated by Langley Research Center, the Lead Center for NASA's scientific and technical information. The NASA STI Program Office provides access to the NASA STI Database, the largest collection of aeronautical and space science STI in the world. The Program Office is also NASA's institutional mechanism for disseminating the results of its research and development activities. These results are published by NASA in the NASA STI Report Series, which includes the following report types:

- $\quad$ TECHNICAL PUBLICATION. Reports of completed research or a major significant phase of research that present the results of NASA programs and include extensive data or theoretical analysis. Includes compilations of significant scientific and technical data and information deemed to be of continuing reference value. NASA's counterpart of peerreviewed formal professional papers but has less stringent limitations on manuscript length and extent of graphic presentations.

- $\quad$ TECHNICAL MEMORANDUM. Scientific and technical findings that are preliminary or of specialized interest, e.g., quick release reports, working papers, and bibliographies that contain minimal annotation. Does not contain extensive analysis.

- CONTRACTOR REPORT. Scientific and technical findings by NASA-sponsored contractors and grantees.
- CONFERENCE PUBLICATION. Collected papers from scientific and technical conferences, symposia, seminars, or other meetings sponsored or cosponsored by NASA.

- SPECIAL PUBLICATION. Scientific, technical, or historical information from NASA programs, projects, and missions, often concerned with subjects having substantial public interest.

- TECHNICAL TRANSLATION. Englishlanguage translations of foreign scientific and technical material pertinent to NASA's mission.

Specialized services that complement the STI Program Office's diverse offerings include creating custom thesauri, building customized data bases, organizing and publishing research results ... even providing videos.

For more information about the NASA STI Program Office, see the following:

- Access the NASA STI Program Home Page at http://www.sti.nasa.gov

- E-mail your question via the Internet to help@sti.nasa.gov

- Fax your question to the NASA Access Help Desk at 301-621-0134

- Telephone the NASA Access Help Desk at 301-621-0390

- Write to:

NASA Access Help Desk

NASA Center for AeroSpace Information 7121 Standard Drive

Hanover, MD 21076 
NASA/TM-2002-211363

AIAA-2001-4924

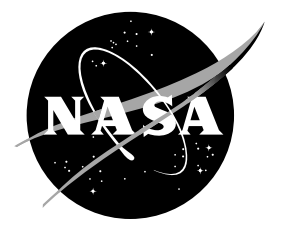

\section{Exposure of Polymer Film Thermal Control Materials on the Materials International Space Station Experiment (MISSE)}

Joyce Dever and Sharon Miller

Glenn Research Center, Cleveland, Ohio

Russell Messer and Edward Sechkar

QSS Group, Inc., Cleveland, Ohio

Greg Tollis

Cleveland State University, Cleveland, Ohio

Prepared for the

International Space Station Utilization-2001

sponsored by the American Institute of Aeronautics and Astronautics

Cape Canaveral, Florida, October 15-18, 2001

National Aeronautics and

Space Administration

Glenn Research Center 


\section{Acknowledgments}

The authors gratefully acknowledge the contributions of Don Jaworske, Bruce Banks, and Kim de Groh (NASA GRC), Eve Wooldridge and Charles Powers (NASA Goddard Space Flight Center), and Wanda Peters (Swales Aerospace). We also thank the MISSE Project Office and Boeing for providing us the opportunity to be a part of MISSE.

Trade names or manufacturers' names are used in this report for identification only. This usage does not constitute an official endorsement, either expressed or implied, by the National Aeronautics and Space Administration.

Available from

NASA Center for Aerospace Information 7121 Standard Drive

Hanover, MD 21076
National Technical Information Service 5285 Port Royal Road Springfield, VA 22100 


\title{
EXPOSURE OF POLYMER FILM THERMAL CONTROL MATERIALS ON THE MATERIALS INTERNATIONAL SPACE STATION EXPERIMENT (MISSE)
}

\author{
Joyce Dever and Sharon Miller \\ National Aeronautics and Space Administration \\ Glenn Research Center \\ Cleveland, Ohio 44135 \\ Russell Messer and Edward Sechkar \\ QSS Group, Inc. \\ Cleveland, Ohio 44135 \\ Greg Tollis \\ Cleveland State University \\ Cleveland, Ohio 44115
}

\begin{abstract}
$\underline{\text { Abstract }}$
Seventy-nine samples of polymer film thermal control (PFTC) materials have been provided by the National Aeronautics and Space Administration (NASA) Glenn Research Center (GRC) for exposure to the low Earth orbit environment on the exterior of the International Space Station (ISS) as part of the Materials International Space Station Experiment (MISSE). MISSE is a materials flight experiment sponsored by the Air Force Research Lab/Materials Lab and NASA. This paper will describe background, objectives, and configurations for the GRC PFTC samples for MISSE. These samples include polyimides, fluorinated polyimides, and Teflon $^{\circledR}$ fluorinated ethylene propylene (FEP) with and without second-surface metalizing layers and/or surface coatings. Also included are polyphenylene benzobisoxazole (PBO) and a polyarylene ether benzimidazole (TOR-LM ${ }^{\mathrm{TM}}$ ). On August 16, 2001, astronauts installed passive experiment carriers (PECs) on the exterior of the ISS in which were located twenty-eight of the GRC PFTC samples for 1-year space exposure. MISSE PECs for 3year exposure, which will contain fifty-one GRC PFTC samples, will be installed on the ISS at a later date. Once returned from the ISS, MISSE GRC PFTC samples will be examined for changes in optical and mechanical properties and atomic oxygen (AO) erosion. Additional sapphire witness samples located on the AO exposed trays will be examined for deposition of contaminants.
\end{abstract}

$\underline{\text { Introduction }}$

Polymer materials commonly used for spacecraft thermal control can experience degradation in optical and mechanical properties due to long duration exposure in the space environment. ${ }^{1,2}$ Teflon $^{\circledR}$ FEP (fluorinated ethylene propylene), a common thermal control material, has been observed to become brittle upon long-term space exposure on the Hubble Space Telescope (HST). ${ }^{2}$ Space environmental effects that can cause damage to polymers include solar ultraviolet radiation, solar flare $\mathrm{x}$-rays, solar wind electrons and protons trapped in Earth's magnetic field, temperature effects, and low Earth orbit AO. Spacecraft surfaces may experience significant temperature excursions during each orbit due to the transitions of the spacecraft between sunlight and shadow. Temperature cycling through the glass transition temperature range has been shown to degrade the mechanical properties of polymers such as Teflon ${ }^{\circledR}$ FEP. ${ }^{3} \quad$ Ultraviolet radiation can damage polymers by breaking chemical bonds, thereby changing the polymer structure. ${ }^{4,5}$ Polymers can experience degradation in mechanical properties upon exposure to radiation. ${ }^{3,5}$ Atomic oxygen reacts chemically with polymeric materials causing oxidation and erosion. ${ }^{4,5}$ It is obvious that a variety of synergistic effects are also possible with this combination of environmental exposure conditions.

While typical polymer film thickness for spacecraft multi-layer insulation MLI ranges between 50 and 
$127 \mu \mathrm{m}$, new spacecraft, such as the Next Generation Space Telescope, propose the use of large ultralightweight inflatable or deployable structures requiring space-facing polymer films of $25 \mu \mathrm{m}$ or less. ${ }^{6}$ Large area ultra-lightweight components will rely on the structural integrity of polymer films that are much thinner than have typically been used in the past. Thinner materials will be more susceptible to radiation damage such as that caused by electrons, vacuum ultraviolet, and soft x-rays, because, for these radiation species, more energy is deposited at the surface than is deposited deeper in the material, and, therefore, a greater fraction of the polymer thickness is susceptible to radiation damage. Coatings applied to polymer surfaces can provide required optical properties, AO protection, and may potentially be tailored to protect the polymer from radiation absorption.

Most of the GRC PFTC samples will assess radiation and temperature effects on a variety of currently used and candidate thermal control materials. Additionally, samples of unprotected polymers have been included to determine AO erosion for one-year and three-year exposure durations. Witness samples of sapphire disks will be analyzed for their surface chemistry following retrieval to determine contamination species in the vicinity of the GRC PFTC samples.

\section{Description of Samples}

Polymers and coatings used in the MISSE GRC PFTC samples are described in Tables 1 and 2, respectively. Where multiple coating layers were deposited, layers are separated by a " $/$ " and are listed in order from closest to farthest from the front, or space-facing, surface. Table 3 lists all the sample types included in the MISSE GRC PFTC experiment. For polymers with coatings, the material description indicates the various layers from the front space-facing surface to the back surface in the following format: front surface coating(s) if used/ polymer/back surface coating(s). Also shown in Table 3 are the environments to which samples will be exposed and the various analyses to be conducted for each material type.

The main objective of the GRC PFTC samples is to assess radiation and temperature effects on optical and mechanical properties of a variety of currently used and candidate thermal control materials, including: traditionally used Teflon $^{\circledR}$ FEP and Kapton ${ }^{\circledR}$, various thin polymer film materials with and without coatings for light-weight inflatable and deployable structures, polymer films with conductive coatings for charge dissipation, and FEP with a special coating for soft $\mathrm{x}$ ray protection. Specimens for radiation/temperature effects testing are designated as specimen types "O" and/or " $T$ ", listed in Table 3. The "O" indicates that the sample will be examined for changes in optical properties of reflectance and transmittance and the " $\mathrm{T}$ " indicates that the sample will be tested for degradation in ultimate tensile strength and elongation to failure. Because it is hoped to use the data to make predictions of durability of these materials in geosynchronous and other orbital environments that do not contain AO, these samples are located on non-AO trays, are resistant to AO attack, or have AO protective coatings so the effects of radiation and temperature can be evaluated without $\mathrm{AO}$ erosion of the polymer. For example, for samples located on AO trays that do not have an inherently $\mathrm{AO}$ protective surface, a film of $\mathrm{SiO}_{\mathrm{x}}-8 \%$ PTFE was ion beam sputter deposited onto the surface as described in Table 2 to prevent $\mathrm{AO}$ erosion but still allow penetration of radiation.

In addition to determining overall changes in optical and mechanical properties for various PFTC materials, some samples were included to assess special issues. Two strips of $25.4 \mu \mathrm{m} \mathrm{LaRC}{ }^{\mathrm{TM}}-\mathrm{CP} 1$ (CP1) were included for tensile testing, one containing a seam and one without a seam, to assess strength and durability of CP1 pieces that have been seamed together using a chemical process. While most samples installed in the tensile specimen holders were installed with a slight amount of slack so there was no stress on the samples due to installation, three tensile samples of silicon oxide coated aluminized Teflon ${ }^{\circledR}$ FEP $\left(\mathrm{SiO}_{\mathrm{x}}-8 \%\right.$ PTFE $/ 127$ $\mu \mathrm{m}$ FEP/VDA) located on the three-year solar and AO trays were installed under tension, i.e. they were pulled tightly in their holders during installation, in order to determine the influence of stress on radiation/temperature-induced polymer degradation. One of the $50.8 \mu \mathrm{m}$ aluminized FEP samples $(50.8 \mu \mathrm{m}$ FEP/VDA) samples located on a one-year solar exposure tray was installed with a $50.8 \mu \mathrm{m}$ FEP cover layer to determine the gradient in mechanical properties degradation as a function of FEP thickness. A stack of ten $50.8 \mu \mathrm{m}$ FEP specimens was installed on a three-year solar exposure tray to investigate changes in optical properties and mechanical properties as a function of FEP thickness. For this specimen stack, tensile samples will be fabricated following retrieval.

An additional objective of the MISSE GRC PFTC samples is to determine $\mathrm{AO}$ erosion yields for various thermal control polymers as indicated by sample type 
TABLE 1 - MISSE GRC PFTC Polymers

\begin{tabular}{|c|l|c|}
\hline $\begin{array}{c}\text { Polymer } \\
\text { Name }\end{array}$ & Description & Manufacturer \\
\hline $\begin{array}{c}\text { Kapton }{ }^{\circledR} \mathrm{HN} \\
\text { Kapton }{ }^{\circledR} \mathrm{H} \\
\text { Kapton }^{\circledR} \mathrm{E}\end{array}$ & aromatic polyimide & DuPont \\
\hline Kapton $^{\circledR} \mathrm{XC}$ & Aromatic polyimide - black & UBE Industries, Ltd. \\
\hline Upilex-S & aromatic polyimide & DuPont \\
\hline Teflon ${ }^{\circledR} \mathrm{FEP}$ & fluorinated ethylene propylene & SRS Technologies \\
\hline LaRC $^{\mathrm{TM}}$-CP1 $(\mathrm{CP} 1)$ & fluorinated polyimide & Foster-Miller \\
\hline PBO & polyphenylene benzobisoxazole & Triton Systems, Inc. \\
\hline TOR-LM
\end{tabular}

TABLE 2 - Coatings used on MISSE GRC PFTC Materials

\begin{tabular}{|c|c|c|}
\hline $\begin{array}{l}\text { Coating Name } \\
\text { (provided by) }\end{array}$ & Description & Purpose \\
\hline $\begin{array}{c}\text { VDA } \\
\text { (various suppliers) }\end{array}$ & Vapor deposited aluminum ( $100 \mathrm{~nm}$ thickness $)$ & $\begin{array}{l}\text { deposited on back-side of polymer as } \\
\text { second-surface reflective layer }\end{array}$ \\
\hline $\begin{array}{l}\mathrm{SiO}_{\mathrm{x}}-8 \% \mathrm{PTFE} \\
(\mathrm{NASA} \text { GRC) }\end{array}$ & $\begin{array}{l}\text { Ion beam co-sputter-deposited coating }(\sim 100 \mathrm{~nm} \\
\text { thickness) from a sputter target consisting of } \\
\text { silicon dioxide with a wedge of } \\
\text { polytetrafluoroethylene (PTFE): } 92 \% \text { (vol.) } \mathrm{SiO}_{\mathrm{x}} \\
(\text { where } \mathrm{x} \approx 2 \text { ) and } 8 \% \text { (vol.) PTFE. }\end{array}$ & $\begin{array}{l}\text { Transparent coating provides AO } \\
\text { protection. Incorporation of PTFE } \\
\text { increases flexibility beyond that of } \\
\mathrm{SiO}_{x} \text { alone. }\end{array}$ \\
\hline $\begin{array}{l}\mathrm{SiO}_{2} / \mathrm{Al}_{2} \mathrm{O}_{3} / \mathrm{Ag} / \mathrm{Al}_{2} \mathrm{O}_{3} \\
\text { referred to as CCAg } \\
\text { (NASA Goddard Space } \\
\text { Flight Center) }\end{array}$ & $\begin{array}{l}\text { Silver composite coating (CCAg) with sputter } \\
\text { deposited coating layers of } 100 \mathrm{~nm} \mathrm{Al}_{2} \mathrm{O}_{3} \text {, } \\
\text { followed by } 150 \mathrm{~nm} \text { silver, } 2000 \mathrm{~nm} \mathrm{Al}_{2} \mathrm{O}_{3} \text {, and } \\
550 \mathrm{~nm} \mathrm{SiO} \text {. }\end{array}$ & $\begin{array}{l}\text { Silver reflective layer; transparent } \\
\mathrm{Al}_{2} \mathrm{O}_{3} \text { and } \mathrm{SiO}_{2} \text { layers to prevent } \\
\text { degradation of silver }\end{array}$ \\
\hline $\begin{array}{c}\mathrm{Ge} \\
\text { (Astral Technologies } \\
\text { Unlimited, Inc.) }\end{array}$ & $\begin{array}{l}\text { Sputter deposited germanium coating }(\sim 50 \mathrm{~nm} \\
\text { thickness) }\end{array}$ & Provides conductive surface \\
\hline $\begin{array}{c}\mathrm{Ag} / \mathrm{Niobium} \\
\text { (Astral Technologies } \\
\text { Unlimited, Inc.) }\end{array}$ & $\begin{array}{l}\text { Sputter deposited silver ( } 135 \mathrm{~nm} \text { thickness }) \\
\text { followed by a niobium layer }(\sim 30 \mathrm{~nm} \text { thickness })\end{array}$ & $\begin{array}{l}\text { Silver deposited on back-side of } \\
\text { polymer as second-surface reflective } \\
\text { layer. Niobium prevents degradation } \\
\text { of silver }\end{array}$ \\
\hline $\begin{array}{c}\mathrm{ATO} / \mathrm{PbO} \\
\text { (Astral Technologies } \\
\text { Unlimited, Inc.) }\end{array}$ & $\begin{array}{l}\text { Sputter deposited coating layers of lead oxide, } \\
\text { PbO, }(\sim 250 \mathrm{~nm} \text { thickness }) \text { and antimony tin oxide, } \\
\text { ATO, }(\sim 35 \mathrm{~nm}) .\end{array}$ & $\begin{array}{l}\text { PbO deposited onto front surface of } \\
\text { polymer for protection from X-ray } \\
\text { penetration; ATO provides } \\
\text { transparent conductive surface } \\
\end{array}$ \\
\hline $\begin{array}{c}\text { ATO } \\
\text { (Astral Technologies } \\
\text { Unlimited, Inc.) }\end{array}$ & Sputter deposited antimony tin oxide $(\sim 35 \mathrm{~nm})$ & Transparent conductive surface \\
\hline
\end{tabular}

"E" in Table 3. Erosion yields for polyimides such as Kapton $^{\circledR} \mathrm{H}$ and for fluoropolymers such as Teflon ${ }^{\circledR}$ FEP have been previously measured. ${ }^{7}$ For more newly developed polyimides such as CP1 and Upilex-S, the MISSE GRC PFTC data will provide long-duration erosion yield data not currently available.

Sapphire witness samples, type "W" in Table 3, will be analyzed for chemical composition of surface contaminants that may be deposited onto the PFTC samples.

\section{Experimental Procedures}

Optical properties samples and procedures

Samples for optical properties measurements were cut using a punch with an inner diameter of approximately 
TABLE 3 - GRC PFTC Samples on MISSE

\begin{tabular}{|c|c|c|c|c|}
\hline Material & $\begin{array}{c}1 \text { year } \\
\text { Solar \& AO }\end{array}$ & $\begin{array}{c}1 \text { year } \\
\text { Solar (no AO) }\end{array}$ & $\begin{array}{c}3 \text { year } \\
\text { Solar \& AO }\end{array}$ & $\begin{array}{c}3 \text { year } \\
\text { Solar (no AO) }\end{array}$ \\
\hline $25.4 \mu \mathrm{m} \mathrm{CP1/VDA}$ & & $\mathrm{O}, \mathrm{T}$ & & $\mathrm{O}$ \\
\hline $\mathrm{SiO}_{\mathrm{x}}-8 \% \mathrm{PTFE} / 25.4 \mu \mathrm{m} \mathrm{CP1/VDA}$ & $\mathrm{O}, \mathrm{T}$ & & $\mathrm{O}, \mathrm{T}(3)$ & \\
\hline $25.4 \mu \mathrm{m} \mathrm{CP1} \mathrm{(stack)}$ & E [6+3] & & $\mathrm{E}[18+3]$ & \\
\hline $25.4 \mu \mathrm{m}$ CP1 strip without seam & & & & $\mathrm{T}$ \\
\hline $25.4 \mu \mathrm{m}$ CP1 strip with seam & & & & $\mathrm{T}$ \\
\hline $25.4 \mu \mathrm{m}$ Upilex-S/VDA & & $\mathrm{O}, \mathrm{T}$ & & $\mathrm{O}, \mathrm{T}(2)$ \\
\hline $\mathrm{SiO}_{\mathrm{x}}-8 \% \mathrm{PTFE} / 25.4 \mu \mathrm{m}$ Upilex-S/VDA & $\mathrm{O}, \mathrm{T}$ & & $\mathrm{O}, \mathrm{T}(3)$ & \\
\hline $25.4 \mu \mathrm{m}$ Upilex-S (stack) & E [6+3] & & $\mathrm{E}[18+3]$ & \\
\hline $25.4 \mu \mathrm{m}$ Kapton ${ }^{\circledR}$ HN/VDA & & $\mathrm{O}, \mathrm{T}$ & & $\mathrm{O}, \mathrm{T}$ \\
\hline $\mathrm{CCAg} / 25.4 \mu \mathrm{m}$ Kapton ${ }^{\circledR} \mathrm{HN} / \mathrm{VDA}$ & $\mathrm{O}, \mathrm{T}$ & & $\mathrm{O}, \mathrm{T}(3)$ & \\
\hline $\mathrm{Al}_{2} \mathrm{O}_{3} / \mathrm{Ag} / 25.4 \mu \mathrm{m}$ Kapton ${ }^{\circledR} \mathrm{HN} / \mathrm{VDA}$ & $\mathrm{O}, \mathrm{T}$ & & $\mathrm{O}, \mathrm{T}(2)$ & \\
\hline $127 \mu \mathrm{m}$ Kapton ${ }^{\circledR} \mathrm{HN}$ (stack) & $\mathrm{E}[2+1]$ & & $\mathrm{E}[6+1]$ & \\
\hline $127 \mu \mathrm{m}$ Kapton ${ }^{\circledR} \mathrm{H}$ (stack) & $\mathrm{E}[2+1]$ & & $\mathrm{E}[6+1]$ & \\
\hline $25.4 \mu \mathrm{m}$ Kapton ${ }^{\circledR}$ E/VDA & & & & $\mathrm{O}, \mathrm{T}$ \\
\hline Ge/25.4 $\mu \mathrm{m}$ Kapton ${ }^{\circledR}$ XC (black)/ Nomex scrim & OE [1] & & OE [1] & \\
\hline $127 \mu \mathrm{m}$ FEP/VDA & OE [1] & & & \\
\hline $50.8 \mu \mathrm{m}$ FEP/VDA & & $\mathrm{O}, \mathrm{T}$ & & $\mathrm{T}$ \\
\hline $50.8 \mu \mathrm{m}$ FEP (stack of 10) & & & & OT \\
\hline $\begin{array}{l}50.8 \mu \mathrm{m} \text { FEP/VDA with } 50.8 \mu \mathrm{m} \text { FEP cover } \\
\text { layer }\end{array}$ & & & & $\mathrm{T}$ \\
\hline $\mathrm{SiO}_{\mathrm{x}}-8 \% \mathrm{PTFE} / 127 \mu \mathrm{m}$ FEP/VDA & $\mathrm{O}, \mathrm{T}$ & & $\mathrm{O}, \mathrm{T}(3)$ & \\
\hline $\mathrm{SiO}_{\mathrm{x}}-8 \% \mathrm{PTFE} / 127 \mu \mathrm{m}$ FEP/VDA, in tension & & & $\mathrm{T}(3)$ & \\
\hline $\mathrm{SiO}_{\mathrm{x}}-8 \% \mathrm{PTFE} / 50.8 \mu \mathrm{m}$ FEP/VDA & & & $\mathrm{O}, \mathrm{T}(3)$ & \\
\hline $127 \mu \mathrm{m}$ FEP/Ag/Niobium & & & OE [1] & \\
\hline $\mathrm{ATO} / \mathrm{PbO} / 127 \mu \mathrm{m} \mathrm{FEP} / \mathrm{Ag} /$ Niobium & & & & $\mathrm{T}$ \\
\hline $\mathrm{ATO} / 127 \mu \mathrm{m}$ FEP/Ag/Niobium & $\mathrm{O}$ & & & \\
\hline $25.4 \mu \mathrm{m}$ PBO & & $\mathrm{O}, \mathrm{T}$ & & $\mathrm{O}, \mathrm{T}$ \\
\hline $50.8 \mu \mathrm{m}$ TOR LM & $\mathrm{O}$ & & $\mathrm{O}, \mathrm{T}(2)$ & \\
\hline Sapphire $\left(\mathrm{Al}_{2} \mathrm{O}_{3}\right)$ disk & $\mathrm{W}(2)$ & & $\mathrm{W}(2)$ & \\
\hline \multicolumn{2}{|l|}{$\begin{aligned} \mathrm{E}= & \text { erosion yield specimen; numbers in [ ] indicate } \\
& \text { layers in stacks } \\
\mathrm{O}= & \text { optical properties specimen } \\
\mathrm{OE}= & \text { sample used for both optical and erosion yield } \\
& \text { measurements }\end{aligned}$} & \multicolumn{3}{|c|}{$\begin{array}{l}=\text { tensile specimen } \\
\mathrm{T}=\text { specimen for optical and mechanical properties } \\
\quad \text { measurements } \\
\quad=\text { witness for contamination } \\
\text { umber in }() \text { given where more than one sample is } \\
\text { cluded }\end{array}$} \\
\hline
\end{tabular}

$2.530 \mathrm{~cm}(0.996 ")$ that produced samples of approximately $2.565 \mathrm{~cm}(1.010$ ") diameter. Following retrieval, flight samples and pristine control samples will be measured for solar absorptance and thermal emittance. Total hemispherical reflectance will be obtained in air between 250 and $2500 \mathrm{~nm}$ using a Perkin-Elmer Lambda-19 spectrophotometer equipped with a $15 \mathrm{~cm}$ integrating sphere. From the spectral data and the air mass zero solar spectrum, solar reflectance and solar absorptance, will be obtained using standard procedures. ${ }^{8,9}$ Thermal emittance will be obtained using an SOC-400t, manufactured by the Surface Optics Corporation. This instrument measures hemispherically detected spectral reflectance over the 
wavelength range 2-25 $\mu \mathrm{m} .{ }^{10}$ Using standard calculations, room temperature hemispherical emittance will be obtained from the spectral data and the room temperature blackbody distribution. ${ }^{9}$

\section{$\underline{\text { Tensile test samples and procedures }}$}

Tensile test samples were fabricated using an ASTM D638 Type V (five) specimen die. ${ }^{11}$ This dog-bone shaped die provides the smallest specimen size per this ASTM standard with a gage length of $7.62 \mathrm{~mm}$, and a gage width of $3.18 \mathrm{~mm}$. In order to occupy the least area possible on the MISSE carriers, tensile specimen holders were designed and fabricated to allow the gage area of samples to receive full space exposure while the grip ends are wrapped through the sample holder fixture and secured underneath the exposed gage area. Figure 1(a) shows an end-on view of a sample loaded in the tensile specimen holder. In order to have enough sample length to grip the ends once the sample was wound through the holder, the tensile specimen die was used so that it did not cut through the grip ends in order to make samples longer than the length of the die. Whereas the tensile die produces samples $6.35 \mathrm{~cm}$ long, a $5.08 \mathrm{~cm}$ long plastic cutting board was used so that the die did not cut the grip ends. The grip ends were then cut to a longer length than provided by the die to produce samples $12.7 \mathrm{~cm}$ in length with $7.62 \mathrm{~cm}$ to one side of center and $5.08 \mathrm{~cm}$ to the other. Once tensile samples were loaded into the holders, excess grip ends were trimmed. Tensile holders for 5 and for 11 tensile specimens, shown in Figures $1 \mathrm{~b}$ and 1c, respectively, were fabricated to fit available areas on the MISSE carriers. The 5-specimen holder occupies an area of $2.54 \mathrm{~cm} \mathrm{x} 10.16 \mathrm{~cm}$ and the 11 -specimen holder occupies an area of $2.54 \mathrm{~cm} \times 17.78 \mathrm{~cm}$.

Following retrieval, a bench-top tensile tester will be used to test MISSE-flown samples along with pristine control samples according to ASTM D-638 to obtain load-displacement data, stress-strain curves, ultimate tensile strength, and elongation to failure.

\section{Erosion yield samples and procedures}

Samples for erosion yield were cut using a punch with an inner diameter of approximately $2.530 \mathrm{~cm}(0.996$ ") that produced samples of approximately $2.565 \mathrm{~cm}$ (1.010") diameter. The equation for calculation of erosion yield is given in equation (1):

$$
\frac{\Delta m}{A \rho F}=E
$$

where

$$
\begin{aligned}
& \Delta m=\text { mass loss }(\mathrm{g}) \\
& A=\text { exposure area }\left(\mathrm{cm}^{2}\right) \\
& \rho=\text { material density }\left(\mathrm{g} / \mathrm{cm}^{3}\right) \\
& F=\text { atomic oxygen fluence }\left(\text { atoms } / \mathrm{cm}^{2}\right) \\
& E=\text { erosion yield }\left(\mathrm{cm}^{3} / \text { atom }\right)
\end{aligned}
$$

To calculate erosion yield for the MISSE samples, preflight and post-flight mass measurements will be used along with the known sample exposure area, polymer density, and calculations of AO fluence as shown in equation (1). Atomic oxygen fluences for the expected MISSE conditions at a $400 \mathrm{~km}$ circular orbit, 51.6degree inclination, and a mission start date of June 2001 have been calculated to be $3.28 \times 10^{21}$ atoms $/ \mathrm{cm}^{2}$ for 1 year, $4.55 \times 10^{21}$ atoms $/ \mathrm{cm}^{2}$ for 1.5 years, and $7.40 \times 10^{21}$ atoms $/ \mathrm{cm}^{2}$ for 3 years. These estimates will be revised based on changes in the actual MISSE mission dates. For example, the 1-year carriers were not actually deployed until August 2001, and the 3-year carriers will be deployed at a later date. In order to assure enough sample thickness to last for the MISSE mission durations, estimates of past space flight erosion yield measurements were used, and contingency thickness was added. For polyimide samples Kapton ${ }^{\circledR} \mathrm{H}$, Kapton ${ }^{\circledR} \mathrm{HN}$, Upilex-S and fluorinated polyimide CP1, erosion yield estimates for MISSE were based on previous space flight characterization of Kapton ${ }^{\circledR} \mathrm{H}$ whose erosion yield was determined to be $3 \times 10^{-24}$ $\mathrm{cm}^{3}$ /atom. ${ }^{7} \quad$ Because of the multitude of data points previously obtained for Kapton ${ }^{\circledR} \mathrm{H}$ (Ref. 7), it will serve as a witness sample for comparison of erosion yields for the other materials being tested. For FEP samples, the erosion yield estimate was $0.337 \times 10^{-24}$ $\mathrm{cm}^{3}$ /atom based on space flight characterization from the Long Duration Exposure Facility. ${ }^{7}$ These erosion yield values were used along with the estimated $\mathrm{AO}$ fluence for the ISS environment of $3.28 \times 10^{21}$ atoms $/ \mathrm{cm}^{2}$ for a one-year exposure duration in order to determine the sample thickness required for one year and three year exposures. Table 3 indicates the number of layers included for stacked erosion yield samples. Two stacks were separately weighed as indicated by the following convention: [number in top stack + number in underlying stack]. The top stacks provide enough thickness for a minimum of 1.5 years of exposure for 1 -year trays and 4.5 years of exposure for 3-year trays to allow contingency in the event of late retrieval. The underlying stacks provide thickness to last at least 9 additional months. Use of separately weighed stacks allows for greater sensitivity in the mass measurements, as the underlying layers do not need to be weighed if they are not eroded.

Erosion yield samples were placed in vacuum desiccators at a pressure of approximately $13.3 \mathrm{~Pa}$ 
(100 mTorr) or less for at least six days to assure full dehydration. Samples were then weighed for pre-flight mass. Where stacks of multiple sample layers were required, samples were weighed as a stack.

\section{$\underline{\text { Contamination witness samples and procedures }}$}

Polished sapphire witness disks $2.52 \mathrm{~cm}$ (0.993") diameter and $1.588 \mathrm{~mm}(0.0625$ ") thick were included among samples on the AO facing trays. These disks will be analyzed using x-ray photoelectron spectroscopy (XPS) to determine the chemistry of deposited contaminants. Sapphire was selected because its chemical formula, $\mathrm{Al}_{2} \mathrm{O}_{3}$, does not contain silicon and can be easily distinguished from silicone, a candidate contaminant of the MISSE samples.

MISSE GRC PFTC Sample Installation on ISS

The MISSE one-year exposure PECs were transported to the ISS and attached onto the Quest Airlock on the exterior of the ISS on August 16, 2001, during the STS 105 Space Shuttle mission. Twenty-eight of the GRC PFTC samples were included on these carriers. Eighteen of them are located on experiment trays that will receive solar exposure with $\mathrm{AO}$ exposure and ten are on trays that will receive solar exposure with no AO. Despite an originally planned mission duration of one year, it is currently planned that the MISSE "oneyear" PECs will actually be exposed to the space environment for 18 months. The location of the oneyear MISSE PECs on the ISS is shown in Figure 2. MISSE PECs that includes a solar exposure tray containing 5 of the GRC PFTC samples as indicated. MISSE PECs for 3-year exposure, which will contain fifty-one GRC PFTC samples, will be installed on the ISS at a later date.

\section{Summary}

The MISSE experiment will provide the opportunity to evaluate the effects of one year and three years in the

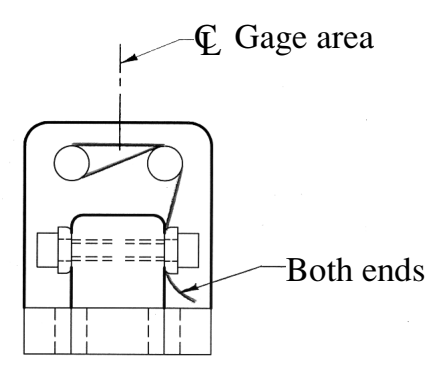

(a)

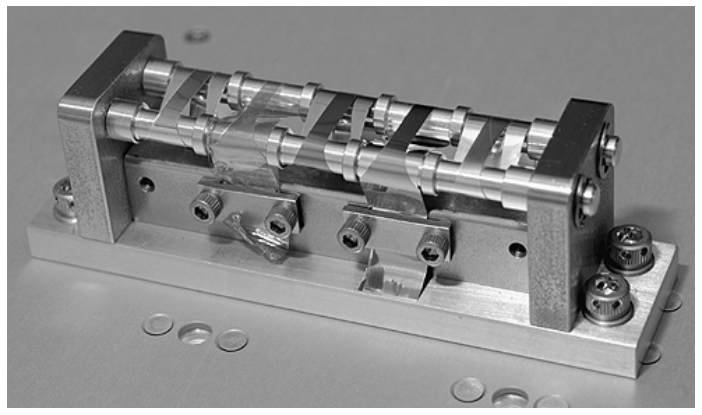

(b)

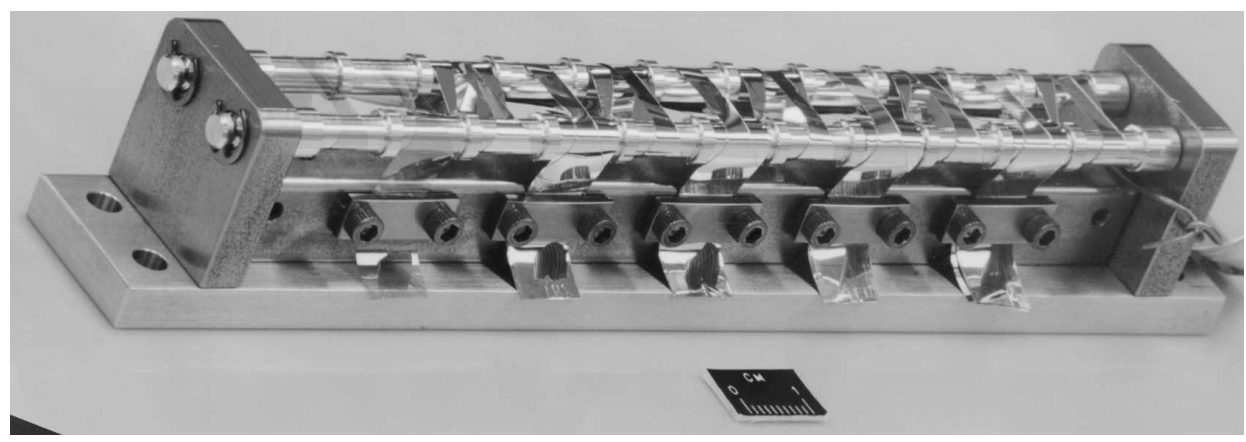

(c)

Figure 1: Tensile specimen holder (a) end on view with sample wound through fixture, (b) fixture containing 5 samples, and (b) fixture containing 11 samples. 


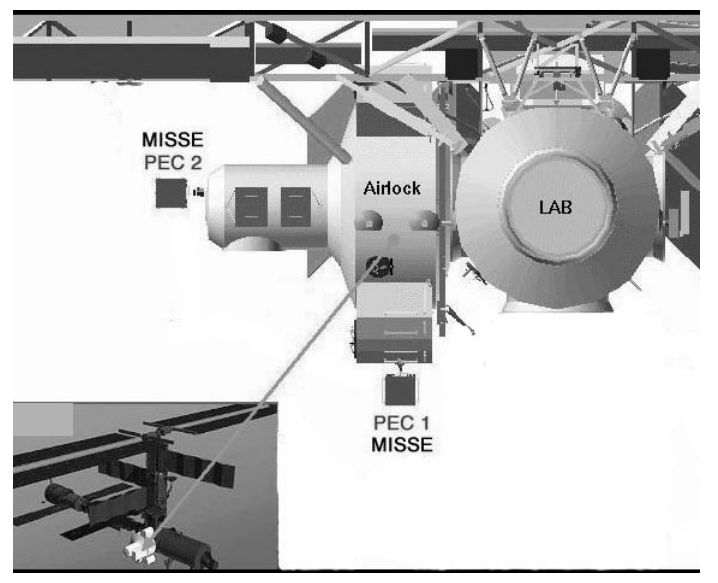

Figure 2: One-year MISSE Passive Experiment Carriers (PECs) location on the ISS.



Figure 3: Astronaut installing a one-year MISSE PEC onto the ISS. Sample tray for solar exposure containing 5 GRC PFTC samples is indicated.

space environment on seventy-nine samples of polymer film thermal control materials provided by NASA Glenn Research Center. These samples include polyimides, fluorinated polyimides, Teflon ${ }^{\circledR}$ FEP, PBO, and TOR-LM ${ }^{\mathrm{TM}}$. Many samples have second-surface metalized layers and surface coatings. Most of these samples will be used to evaluate the effects of the low Earth orbit radiation and temperature environments on optical and mechanical properties degradation of the polymer film materials. Other samples will be used to evaluate AO erosion yield. Sapphire witness samples will be used to evaluate the local contamination environment. MISSE experiment carriers for one-year exposure were installed onto handrails on the exterior of the ISS on August 16, 2001. MISSE experiment carriers for 3-year exposure will be installed on the ISS at a later date.

\section{$\underline{\text { References }}$}

1. Hall, D.F., Fote, A.A., "10 Year Performance of Thermal Control Coatings at Geosynchronous Altitude," AIAA-91-1325, June 1991.

2. Townsend, J.A., Hansen, P.A., McClendon, M.W., de Groh, K.K., Banks, B.A., "Hubble Space Telescope metallized Teflon ${ }^{\circledR}$ FEP thermal control materials: on-orbit degradation and post-retrieval analysis," High Performance Polymers, Vol. 11, No. 1, March 1999.

3. Reed, R.P., Schramm, R.E., and Clark, A.F., Cryogenics, February 1973, pp. 67-82.

4. Dever, J.A., "Low Earth Orbital Atomic Oxygen and Ultraviolet Radiation Effects on Polymers," NASA Technical Memorandum 103711, February 1991.

5. Tribble, A.C., The Space Environment: Implications for Spacecraft Design, Princeton University Press, Princeton, NJ, 1995, p. 155.

6. Perrygo, C., Choi, M., Parrish, K., Schunk, G., Stanley, D., Wooldridge, E., "Passive thermal control of the NGST," SPIE 3356-66, 1998.

7. B.A. Banks, "The use of fluoropolymers in space applications," Chapter 4 in Modern Fluoropolymers, edited by John Scheirs, John Wiley \& Sons, 1997.

8. ASTM E 903-82, "Standard Test Method for Solar Absorptance, Reflectance, and Transmittance of Materials Using Integrating Spheres," 1982, Reapproved 1992.

9. J.H. Henninger, "Solar Absorptance and Thermal Emittance of Some Common Spacecraft ThermalControl Coatings," NASA Reference Publication 1121, April 1984.

10. D.A. Jaworske, T.J. Skowronski, "Portable Infrared Reflectometer for Evaluating Emittance," Proceedings of the Space Technology and Applications International Forum (STAIF) 2000, Albuquerque, NM, February 2000, pp. 791-796.

11. ASTM D 638-95, "Standard Test Method for Tensile Properties of Plastics," 1995. 
Public reporting burden for this collection of information is estimated to average 1 hour per response, including the time for reviewing instructions, searching existing data sources, gathering and maintaining the data needed, and completing and reviewing the collection of information. Send comments regarding this burden estimate or any other aspect of this collection of information, including suggestions for reducing this burden, to Washington Headquarters Services, Directorate for Information Operations and Reports, 1215 Jefferson Davis Highway, Suite 1204, Arlington, VA 22202-4302, and to the Office of Management and Budget, Paperwork Reduction Project (0704-0188), Washington, DC 20503.

\begin{tabular}{|l|l|l|}
\hline 1. AGENCY USE ONLY (Leave blank) & $\begin{array}{c}\text { 2. REPORT DATE } \\
\text { February } 2002\end{array}$ & $\begin{array}{r}\text { 3. REPORT TYPE AND DATES COVERED } \\
\text { Technical Memorandum }\end{array}$ \\
\hline
\end{tabular}

\section{TITLE AND SUBTITLE}

\section{FUNDING NUMBERS}

Exposure of Polymer Film Thermal Control Materials on the Materials

International Space Station Experiment (MISSE)

\section{6. $\operatorname{AUTHOR(S)}$}

Joyce Dever, Sharon Miller, Russell Messer, Edward Sechkar, Greg Tollis

\section{PERFORMING ORGANIZATION NAME(S) AND ADDRESS(ES)}

National Aeronautics and Space Administration

John H. Glenn Research Center at Lewis Field

Cleveland, Ohio 44135-3191
WU-755-1A-13-00

8. PERFORMING ORGANIZATION REPORT NUMBER

E-13184

\section{SPONSORING/MONITORING AGENCY NAME(S) AND ADDRESS(ES)}

National Aeronautics and Space Administration

Washington, DC 20546-0001
10. SPONSORING/MONITORING AGENCY REPORT NUMBER

NASA TM-2002-211363

AIAA-2001-4924

\section{SUPPLEMENTARY NOTES}

Prepared for the International Space Station Utilization-2001 sponsored by the American Institute of Aeronautics and Astronautics, Cape Canaveral, Florida, October 15-18, 2001. Joyce Dever and Sharon Miller, NASA Glenn Research Center; Russell Messer and Edward Sechkar, QSS Group, Inc., Cleveland, Ohio; and Greg Tollis, Cleveland State University, Cleveland, Ohio. Responsible person, Joyce Dever, organization code 5480, 216-433-6294.

12a. DISTRIBUTION/AVAILABILITY STATEMENT

\section{2b. DISTRIBUTION CODE}

Unclassified - Unlimited

Subject Category: 27

Distribution: Nonstandard

Available electronically at http://gltrs.grc.nasa.gov/GLTRS

This publication is available from the NASA Center for AeroSpace Information, 301-621-0390.

\section{ABSTRACT (Maximum 200 words)}

Seventy-nine samples of polymer film thermal control (PFTC) materials have been provided by the National Aeronautics and Space Administration (NASA) Glenn Research Center (GRC) for exposure to the low Earth orbit environment on the exterior of the International Space Station (ISS) as part of the Materials International Space Station Experiment (MISSE). MISSE is a materials flight experiment sponsored by the Air Force Research Lab/Materials Lab and NASA. This paper will describe background, objectives, and configurations for the GRC PFTC samples for MISSE. These samples include polyimides, fluorinated polyimides, and Teflon ${ }^{\circledR}$ fluorinated ethylene propylene (FEP) with and without second-surface metalizing layers and/or surface coatings. Also included are polyphenylene benzobisoxazole (PBO) and a polyarylene ether benzimidazole (TOR-LM ${ }^{\mathrm{TM}}$ ). On August 16, 2001, astronauts installed passive experiment carriers (PECs) on the exterior of the ISS in which were located twenty-eight of the GRC PFTC samples for 1-year space exposure. MISSE PECs for 3-year exposure, which will contain fifty-one GRC PFTC samples, will be installed on the ISS at a later date. Once returned from the ISS, MISSE GRC PFTC samples will be examined for changes in optical and mechanical properties and atomic oxygen $(\mathrm{AO})$ erosion. Additional sapphire witness samples located on the AO exposed trays will be examined for deposition of contaminants.

\section{SUBJECT TERMS}

Polymers; Earth orbital environments

15. NUMBER OF PAGES

13

16. PRICE CODE

\begin{tabular}{|c|c|c|}
\hline $\begin{array}{c}\text { 17. SECURITY CLASSIFICATION } \\
\text { OF REPORT } \\
\text { Unclassified }\end{array}$ & $\begin{array}{c}\text { 18. SECURITY CLASSIFICATION } \\
\text { OF THIS PAGE } \\
\text { Unclassified }\end{array}$ & $\begin{array}{c}\text { 19. SECURITY CLASSIFICATION } \\
\text { OF ABSTRACT } \\
\text { Unclassified }\end{array}$ \\
\hline
\end{tabular}

NSN 7540-01-280-5500
Standard Form 298 (Rev. 2-89)

Prescribed by ANSI Std. Z39-18 298-102 